Research Article

\title{
Proximate Body Composition of Talang Queenfish (Scomberoides commersonnianus Lacépède, 1801) from Pakistan
}

\author{
Sheikh Muhammad Azam ${ }^{1,2}$ and Muhammad Naeem ${ }^{1 *}$
}

${ }^{1}$ Institute of Pure and Applied Biology (Zoology Division), Bahauddin Zakariya University, Multan, Pakistan: ${ }^{2}$ Department of Zoology, Division of Science E' Technology, University of Education, Lahore, Pakistan.

\begin{abstract}
Proximate body composition implies composition of water, ash, protein and lipids. Basic purpose of the present work was to avow nutritious status of Scomberoides commersonnianus. Therefore, current study analysis was performed to analyze body composition of the studied fish. A total of 73 specimens of $S$. commersonnianus having different size, ranged 94.5 to $1183 \mathrm{~g}$ of body weight and 20.5 to $56.9 \mathrm{~cm}$ in total length were randomly chosen from Arabian Sea Karachi, Sindh, Pakistan for analysis of proximate study. The mean percent values of different constituents were $73.95 \%$ water, $3.58 \%$ ash, $3.98 \%$ fat, $18.48 \%$ protein and $22.46 \%$ organic contents in wet weight of the fish. The relationships of percent $\mathrm{H}_{2} \mathrm{O}$ with other constituents in wet body weight were found to be highly significant $(\mathrm{P}<0.001)$, however the relation with percent ash, fat, organic contents and protein in dry body weight were non-significant $(\mathrm{P}>0.05)$. Highly significant relationships were also observed for fish size (weight and total length) with all other body constituents in log-transformed data. Condition factor had highly significant relationships with percent ash, water, protein, organic contents while significant relation was observed with percent fat.

Received | March 19, 2021; Accepted | August 28, 2021; Published | December 02, 2021

*Correspondence | Muhammad Naeem, Department of Zoology, Division of Science \& Technology, University of Education, Lahore, Pakistan;Email: dr_naeembzu@yahoo.com

Citation | Azam, S.M. and M. Naeem. 2022. Proximate body composition of talang queenfish (Scomberoides commersonnianus Lacépède, 1801) from Pakistan. Sarhad Journal of Agriculture, 38(1): 204-209.

DOI | https://dx.doi.org/10.17582/journal.sja/2022/38.1.204.209

Keywords $\mid$ Scomberoides commersonnianus, Proximate body composition, Lipids, Ash, Protein, Marine fish
\end{abstract}

\section{Introduction}

$\mathrm{F}$ esh of fish is considered as more valuable with high proteinious contents to be consume in comparison with various form of animal meat of different species (Louka et al., 2004). Proximate body composition of fish has recently in consideration for health and nutritional purpose (Tobin et al., 2006). On relation by growing interest in quality and safety of various items of fishes (Dumas et al., 2010). It is consider as very important aspect among nutritional concern (Breck, 2014) that influence the nutrition values and its consumption for fish quality (Azam et al., 2004). It is suggested that with evaluation for content of moisture for relative water, fat and protein in fish (Naeem and Ishtiaq, 2011). To report the differences among individual sizes between different fishes proximate composition is generally illustrate percent dry and wet body weight. Relationship between proximate body composition of animals and their sizes is also observed (Rivera-Torres et al., 2011). Comparable fish relationships reveals that percentage of various body composition as ash, water, protein and fat in fish depend upon their sizes (Naeem and Ishtiaq, 2011).

Fish contains water, protein, fat and small amount of minerals and carbohydrates (Haruna, 2003). The estimation of fish nutritive value that relies on it's proximate body composition (Prado et al., 2009). Particular calculation of proximate composition is performed 
in economically viable species that are cultured with specific weight of body for food, and for the enchantment in efficiency as well as profitability. Many studies can be conducted to predict the proximate composition from its body weight of fish (Naeem et al., 2016). Analysis of proximate body composition on a large scale, is usually utilized by scientist for screening of condition and health of fish (Aberoumad and Pourshafi, 2010).

The aim of present study was to evaluate proximate body composition of a marine fish, Scomberoides commersonnianus from Pakistan.

\section{Materials and Methods}

Total 73 specimens of a marine fish, Scomberoides commersonnianus, having different sizes ranges from 94.5 to $1183 \mathrm{~g}$ of body weight and 20.5 to $56.9 \mathrm{~cm}$ in total length were randomly chosen from Arabian Sea Karachi, Sindh, Pakistan for analysis of proximate composition. Samples were transported within ice containing plastic packing to Fisheries Research Laboratory in the IP E $A B$ (Zoology Division), BZU Multan, Pakistan. Samples were cleaned by removing from box with a towels. Fish wet weight of each specimen was measured by using digital electric balance (MP3000; Cho, Japan) and total length by wooden measuring board. For water content estimation, each of the fish sample was put in pre-weighted aluminum foil and kept in oven (Memmert) on $60-70^{\circ} \mathrm{C}$ for drying purpose until constant weight. Dried samples were grinded to make homogenized powder. For calculation of content of ash contents in each specimen, $1 \mathrm{~g}$ powder sample of fish was taken in pre-weighted china crucible and placed in muffle furnace at $450-500^{\circ} \mathrm{C}$ for 24 hours and was weighed again.

For estimation of fat content, mixture of chemicals with 2:1 ratio of chloroform and methyl alcohol was applied (Salam and Davies, 1994). By taking $1 \mathrm{~g}$ of dry powder tissue in test tube, $10 \mathrm{ml}$ of methyl alcohol and chloroform mixture was mixed with glass stirrer. These mixtures were kept overnight, then shifted in pre weighed glass bottles and placed in oven at $40-50^{\circ} \mathrm{C}$ till the dry mass of lipid left behind. Protein contents were calculated by using difference method, by subtracting fat and ash content from dry fish mass (Salam and Davies, 1994; Naeem et al., 2016). Condition factor was assessed by techniques of Wooton (1990).

To assess effect of total length, weight and condition factor on the fish proximate composition, regression analysis was performed by using following equation: based on various body content to examine these association with studied parameters by using following formula:

$$
Y=a+b X
$$

\section{Results and Discussion}

The percent mean and standard deviation were 73.95 $\pm 3.02 \%$ for water, $3.58 \pm 0.75 \%$ for ash (wet weight), $13.72 \pm 2.19 \%$ for ash (dry body weight), $3.981 .12 \%$, $15.30 \pm 4.01 \%$ for fat (wet and dry weight of body), $18.48 \pm 2.42 \%$ for protein (wet body weight), $70.97 \pm$ $4.78 \%$ protein content (dry body weight) and $22.46 \pm$ $2.59 \%$ for organic content (Wet body weight), 86.28 $\pm 2.19 \%$ for organic content (dry weight of body) (Table 1).

Table 1: Mean value and ranges of various body constituents of Scomberoides commersonnianus. $(n=73)$.

\begin{tabular}{|lll|}
\hline Body constituents & Mean \pm SD & Ranges \\
\hline Water content (\%) & $73.95 \pm 3.02$ & $69.39-81.83$ \\
\hline Ash content (\%Wet wt.) & $3.58 \pm 0.75$ & $2.13-5.30$ \\
\hline Ash content (\%dry wt.) & $13.72 \pm 2.19$ & $8.00-19.00$ \\
\hline Fat content (\%wet wt.) & $3.98 \pm 1.12$ & $2.03-6.30$ \\
\hline Fat content (\% dry wt.) & $15.30 \pm 4.01$ & $7.99-24.00$ \\
Protein contents (\%wet wt.) & $18.48 \pm 2.42$ & $12.18-21.97$ \\
Protein contents (\%dry wt.) & $70.97 \pm 4.78$ & $60.00-82.02$ \\
Organic contents (\%wet wt.) & $22.46 \pm 2.59$ & $16.00-26.49$ \\
\hline Organic contents (\%dry wt.) & $86.28 \pm 2.19$ & $81.00-92.00$
\end{tabular}

$S D=$ Standard deviation

The relationship of percent $\mathrm{H}_{2} \mathrm{O}$ with different body constituent (wet weight of body) were found to be highly significant $(\mathrm{P}<0.001)$ except their relation with $\%$ organic contents, fat protein and ash (dry weight of body) were non significant $(\mathrm{P}>0.05)$. Percent water showed inverse relation with all constituents except \%protein, \%fat and \%organic constituents in dry weight (Table 2).

By studying the each variable total values of proximate body composition by log transformation on water, fat, ash and protein constituent and by regression analysis against log wet body weight of body and with log total length highly significant correlation was observed. Log body weight shown positive relationship with all studied components (Table 3), similarly positive trend of log total length with all other constituents was also found (Table 4). 
Table 2: Statistical analysis of percent water content with percent body constituent of S. commersonnianus $(n=73)$.

$\begin{array}{llllll}\text { Relationship } & \text { r } & \text { a } & \text { b } & \text { SE(b) } & \text { T Value b=0 } \\ \text { \%Water - \%Ash wet wt. } & -0.650^{\text {***** }} & 15.581 & -0.162 & 0.023 & -7.150 \\ \text { \%Water - \%Ash dry wt. } & 0.141^{\text {n.s }} & 21.280 & -0.102 & 0.086 & -1.191 \\ \text { \% Water - \%Fat wet wt. } & 0.392^{\text {*** }} & 14.726 & -0.145 & 0.041 & -3.564 \\ \text { \%Water - \%Fat dry wt. } & 0.044^{\text {n.s }} & 10.931 & 0.059 & 0.159 & 0.372 \\ \text { \%Water - \%Protein wet wt. } & 0.862^{\text {*** }} & 69.693 & -0.692 & 0.049 & -14.256 \\ \text { \%Water - \%Protein dry wt. } & 0.027^{\text {n.s }} & 67.789 & 0.043 & 0.189 & 0.228 \\ \text { \%Water - \%Organic Content wet wt. } & 0.975^{\text {**** }} & 84.419 & -0.838 & 0.023 & -36.925 \\ \text { \%Water - \%Organic Content dry wt. } & 0.141^{\text {n.s }} & 78.720 & 0.102 & 0.086 & 1.191\end{array}$

$r=$ Correlation Coefficient; $a=$ Intercept $; b=$ Slope; S.E $=$ Standard Error; $* * * *=0.001 ; n . s=P>0.005$

Table 3: Statistical analysis of log wet body weight (Wt.) with various $\% \log$ body constituent of $S$. commersonnianus $(n=73)$.

$\begin{array}{llllll}\text { Relationship } & \text { r } & \text { a } & \text { b } & \text { S.E(b) } & \text { T Value b=1 } \\ \text { Log Body wt. - Log Water } & 0.999^{* * * * *} & -0.060 & 0.973 & 0.004 & -230.01 \\ \text { Log Body wt. - Log Ash } & 0.981^{* * * *} & -1.723 & 1.101 & 0.026 & -36.96 \\ \text { Log Body wt. - Log Fat } & 0.971^{* * * *} & -1.850 & 1.163 & 0.034 & -27.97 \\ \text { Log Body wt. - Log Protein } & 0.991^{* * * *} & -0.905 & 1.063 & 0.017 & -58.05 \\ \text { Log Body wt. - Log Organic contents } & 0.995^{* * *} & -0.861 & 1.079 & 0.013 & -75.00\end{array}$

For abbreviations and statistical details, see Table 2.

Table 4: Statistical analysis of $\log T L$ with \% log body constituent in S. commersonnianus.

$\begin{array}{llllll}\text { Relationship } & \text { r } & \mathbf{a} & \mathbf{b} & \text { SE(b) } & \text { T Value b=3 } \\ \text { Log TL-Log Water } & 0.996^{* * *} & -1.388 & 2.466 & 0.028 & -106.51 \\ \text { Log TL-Log Ash } & 0.980^{* * *} & -3.236 & 2.796 & 0.069 & -40.96 \\ \text { Log TL- Log Fat } & 0.964^{* * *} & -3.421 & 2.937 & 0.097 & -28.14 \\ \text { Log TL- Log Protein } & 0.989^{* * *} & -2.362 & 2.698 & 0.049 & -59.14 \\ \text { Log TL- Log Organic contents } & 0.992^{* * *} & -2.335 & 2.735 & 0.042 & -68.09\end{array}$

For abbreviations and statistical details, see Table 2.

Table 5: Statistical analysis of condition factor with various $\%$ body constituent in $S$. commersonnianus.

$\begin{array}{llllll}\text { Relationship } & \text { r } & \text { a } & \text { b } & \text { S.E(b) } & \text { T value b=0 } \\ \text { Condition Factor - \%Water } & 0.548^{* * * *} & 65.386 & 10.697 & 1.950 & 5.485 \\ \text { Condition Factor -\%Ash } & -0.411^{* * *} & 5.190 & -2.005 & 2.125 & -0.943 \\ \text { Condition Factor - \%Fat } & -0.352^{* *} & 6.020 & -2.547 & 2.182 & -1.167 \\ \text { Condition Factor - \%Protein } & -0.392^{* * *} & 23.404 & -6.145 & 2.145 & -2.865 \\ \text { Condition Factor - \%Organic contents } & -0.519^{* * * *} & 29.424 & -8.692 & 1.994 & -4.360\end{array}$

For abbreviations and statistical details, see Table 2.

Condition factor showed inverse correlation with percent fat, organic contents, ash and protein while has positive with percent water. Condition factor showed highly significant relationship with percent water, ash, protein, organic contents while significant relation $(\mathrm{P}<0.01)$ with percent fat was observed (Table 5$)$.
Results of current study were in agreement with the findings of Lal and Naeem (2021) in Terapon jerbua $73.22 \%$ and in Clarias gariepinus (74.3\%) studied by Osibona et al. (2009). But the results deviated in fish Ctenopharyngodon idella $77.34 \%$ by Scherer et al. (2006); Perca fluviatilis $80.2 \%$ by Orban et al. (2007) and Osibona et al. (2009) in Tilapia zillii 
$80.4 \%$. Present method of body composition analysis with its relationships to other body components is used as a predictor for fish composition. Moreover, it is less expensive within short timeframe (Hartman and Margraf, 2008). Inverse correlation between fat (wet weight) and protein (wet weight) with percent water may provide cost effective and quick index by mean of their energy contents to measure the content of water (Hislop et al., 1991). Present study found in agreement with this study. Similarly, different investigators have been observed same trend in whole fish (Elliott, 1976; Osibona et al., 2009). Ash represents in smaller proportion in composition of fish. In present study the ash content was found $3.58 \%$. Ash content was found contradictory from the findings of Kamal et al. (2007) in Clarias batrachus 3.74\% and Anabas testudineus (3.31\%) are in general agreement. Hossain et al. (1999) reported that the content of fat of different fish species ranges from 1.87-9.55\%. In present study, fat content was found $3.98 \%$ in wet weight of S. commersonnianus. Fishes having less than 5\% lipid content are considered lean (Ackman, 1989). Protein content (wet weight) was estimated as $18.48 \%$ in present study. Similar findings of protein contents are presented in Chanda gariepinus (18.8\%), Amblypbaryngodon mola (18.46\%) and C. nama (18.26\%) by Mazumder et al. (2008).

Analysis of proximate body composition by log transformation on water, fat, ash and protein constituents and regression analysis against log wet body weight of body and with log total length highly significant positive correlation were observed. Similar significant positive correlation by $\log$ regressions were also reported by Khalid and Naeem (2018) in C. idella.

Although different research studies (Naeem et al., 2016) using condition factor for estimation of fish body composition, but other research studied (Naeem and Ishtiaq, 2011) remained unsuccessful for reporting significant relation between body constituent and condition factor. The variation can be because of proximate body composition may varies with feed, condition factor or body size (Ishtiaq and Naeem, 2019). Pradhan et al. (2014) reported a significant correlation among different body constitutents (lipid, ash, moisture and protein) and condition factor in Catla catla. Present study should also revealed significant relationship between condition factors and various body constituents.

\section{Conclusions and Recommendations}

Results of study reveal that different proximate body composition constitutents (fat, protein, water, organic content and ash) not only be varies with changing in species, but also by changing body size and condition factor of a fish species. The results indicated high proteinaceous value (18.48\% of wet body weight); so, it should also promoted as very useful for fishing industries for processing of food for nutritionists and marketers and to increase the consumption of meat. Moreover, little work have done, more work on this fish species will have to be done to coup with per capita meat consumption.

\section{Novelty Statement}

This study provides nutrition insight of a low cast and valuable marine fish (Scomberoides commersonnianus), found in coastal areas of Pakistan.

\section{Author's Contribution}

Sheikh Muhammad Azam: Conduction of experimentation, data collection, did statistical analysis and wrote manuscript.

Muhammad Naeem: Has provided guideline for completion of research experimentation and resources for completion of research.

\section{Conflict of interest}

Authors have declared no conflict of interest.

\section{References}

Aberoumad, A. and K. Pourshafi. 2010. Chemical and proximate composition properties of different fish species obtained from Iran. World J. Fish Mar. Sci. 2(3): 237-239.

Ackman, R.G. 1989. Nutritional composition of fats in seafoods. Prog. Food Nutr Sci., 13: 161-241.

Azam, K., M.Y.Ali, M. Asaduzzaman, M. Z. Basher and M.M. Hossain. M.M., 2004. Biochemical assessment of selected fresh fish. J. Biol. Sci. 4:9-10.

Breck,J.E. 2014. Body Composition in Fishes: Body Size Matters. Aquaculture. 433: 40-49. https:// doi.org/10.1016/j.aquaculture.2014.05.049

Dumas, A., J. France and D, Bureau. 2010. Modelling growth and body composition in fish 
nutrition: where have we been and where are we going? Aqua. Res. 41: 161-181. https://doi. org/10.1111/j.1365-2109.2009.02323.x

Elliott, M. 1976. Body composition of brown trout, Salmo trutta $\mathrm{L}$. in relation to temperature and size. J. Comp. Physiol. 114: 191-202. https:// doi.org/10.2307/3779

Hartman, K.J. and F.J. Margraf. 2008. Common relationships among proximate composition components in fishes. J. Fish Biol. 73: 23522360.

Haruna, A.B. 2003. Aquaculture in the tropics theory and practice. Al-Hassan Kano. 432.

Hislop, J.R.G., M.P. Harris and J.G.M. Smith. 1991. Variation in the calorific value and total energy content of the lesser sandeel (Ammodytes marinus) and other fish preyed on by seabirds. J. Zool. Lond. 224: 501-517. https://doi. org/10.1111/j.1469-7998.1991.tb06039.x

Hossain, M.A., K.A. Fsana and S.A.K.M., Azad. 1999. Nutritional value of some small indigenous fish species (sis) of Bangladesh. Bangladesh J. Fish. 3: 77-85.

Ishtiaq, A. and M. Naeem. 2019. Effect of dietary protein levels on body composition of Catla catla from Pakistan. Sindh Univ. Res. J. (Sci. Ser.). 51 (2): 309-318. https://doi.org/10.26692/ sujo/2019.6.51

Kamal, D., A.N. Khan, M.A. Rahman and F. Ahamed. 2007. Biochemical composition of some small indigenous fresh water fishes from the river Mouri, Khulna, Bangladesh. Pak. J. Bio. Sci. 10(9): 1559-1561.

Khalid, M. and M. Naeem. 2018. Proximate analysis of grass carp (Ctenopharyngodon idella) from Southern Punjab, Pakistan. Sarhad J. Agric. 34(3): 632-639. https://doi.org/10.17582/ journal.sja/2018/34.3.632.639

Lal, V. and M. Naeem. 2021. Proximate composition analysis of marine fsh, Terapon jarbua, from Pakistan. Sarhad J. Agric. 37(1): 290-295 https://doi.org/10.17582/journal. sja/2021/37.1.290.295

Louka, N., F. Juhel, V. Fazilleau and P. Loonis. 2004. A novel colorimetry analysis used to compare different drying fish processes. Food Control. 15: 327-334. https://doi.org/10.1016/ S0956-7135(02)00119-6

Mazumder, M.S.A., M.M. Rahman, A.T.A. Ahmed, M. Begum and M. Hossain. A. 2008. Proximate composition of some small indige- nous fish species (sis) in Bangladesh. Int. J. Sustain. Crop Prod. 3(4): 18-23.

Naeem, M. and A. Ishtiaq. 2011. Proximate composition of Mystus bleekeri in relation to body size and condition factor from Nala Daik, Sialkot, Pakistan. Afr. J. Biotechnol. 10(52): 1076510763. https://doi.org/10.5897/AJB10.2339

Naeem, M., A. Salam and A. Zuberi. 2016. Proximate composition of fresh water Rainbow Trout (Oncorbynchus mykiss) in relation to body size and condition factor from Pakistan. Pak. J. Agric. Sci. 53(2): 497-502. https://doi. org/10.21162/PAKJAS/16.2653

Orban, E., T. Nevigato, M. Masci, G. D. Lena, I. Casini, R. Caproni, L. Gambelli, P. D. Angelis, M. Rampacci. 2007. Nutritional quality and safety of European perch (Perca fluviatilis) from three lakes of Central Italy, Food Chem. 100(2): 482-490. https://doi.org/10.1016/j. foodchem.2005.09.069

Osibona, A.O., K.1. Kusemiju and G.R. Akande. 2009. Fatty acid composition and amino acid profile of two freshwater species, African catfsh (Clarias gariepinus) and tilapia (Tilapia zillii). Afr. J. Food Agric. Nut. Dev. 9(1): 608-621. https://doi.org/10.4314/ajfand.v9i1.19216

Pradhan, S.C., A.K. Patra and A. Pal. 2014. Seasonal analysis of the biochemical composition of muscle and liver of Catla catla in a tropical climate of India. Comp. Clin. Pathol. 24 (3): 593-603. https://doi.org/10.1007/s00580-0141952-4

Prado, R., C. Rioboo, C. Herrero and A. Cid. 2009. The herbicide paraquat induces alterations in the elemental and biochemical composition of nontarget microalgal species. Chemosphere. 76:1440-1444. https://doi.org/10.1016/j.chemosphere.2009.06.003

Rivera-Torres, V., J. Noblet and J.van Milgen. 2011. Changes in chemical composition in male turkeys during growth. Poult. Sci. 90: 68-74. https://doi.org/10.3382/ps.2010-00633

Salam, A. and P.M.C. Davies. 1994. Body composition of northern pike (Esox lucius L.) in relation to body size and condition factor. Fish. Res., 19: 193-204. https://doi.org/10.1016/01657836(94)90038-8

Scherer, R., P.R. Augusti, V.C. Bochi, C. Steffens, L.L.M. Fries, A.P.Daniel, and T. Emanuelli. 2006. Chemical and microbiological quality of grass carp (Ctenopharyngodon idella) slaugh- 
tered by different methods. Food Chem. 99(1): 136-142. https://doi.org/10.1016/j.foodchem.2005.06.048

Tobin, D., A. Kause, E.A. Mntysaari, S.A.M. Martin, D.F. Houlihan, A. Dobly, A. Kiessling, K. Rungruangsak-Torrissen, O. Ritola and K. Ruohonen. 2006. Fat or lean? The quantitative ge- netic basis for selection strategies of muscle and body composition traits in breeding schemes of rainbow trout (Oncorbynchus mykiss). Aquaculture. 261: 510-521. https://doi.org/10.1016/j. aquaculture.2006.07.023

Wootton, R.J. 1990. Ecology of Teleost Fishes. Chapman and Hall, London. 